\title{
Hardness and Tensile Properties of Prophylactic Knee Brace Produced from Cow Bone and Periwinkle Shell Composites
}

\author{
Abdulkareem Sulaiman, Adekaye Timothy Adeniyi, Abdulrahim Abdulbaqi Toyin, Shuaib- \\ Babata Yusuf Lanre, Ajiboye Tajudeen Kolawole, Ahmed Ismail Idowu, Ibrahim Hassan Kobe, \\ Adebisi Jelil Adekunle and Yahaya Taiwo
}

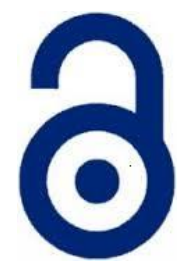

Received: 15 February 2019

Accepted: 27 March 2019

Published: 20 June 2019

Publisher: Deer Hill Publications

(c) 2019 The Author(s)

Creative Commons: CC BY 4.0

\begin{abstract}
Application of reinforced aluminium scrap for the production of prophylactic knee brace (Pkb) particularly with agrowaste materials is rarely available. In this work, hardness and tensile properties of aluminium alloy (Al 6063) straps reinforced with cow bone ( $\mathrm{Cb}$ ) and periwinkle shell (Ps) for the production of Pkb were investigated. The $\mathrm{Cb}$ and $\mathrm{Ps}$ sourced were cleaned and the $\mathrm{Cb}$ was sun-dried for 4 weeks before crushing with Denver laboratory Ball mill (Model: 48-D0500/Q). The Ps was also crushed, sun-dried for 7 days and treated in the oven (Model SDO/225) at $110{ }^{\circ} \mathrm{C}$ for 30 minutes to remove moisture. The particle size of $75 \mu \mathrm{m}$ was used to cast six (6) each of aluminium/cowbone $(\mathrm{Al} / \mathrm{Cb})$ and aluminium/periwinkle shell $(\mathrm{Al} / \mathrm{Ps})$ composites. The cast aluminium composites of $\mathrm{Pkb}$ and original $\mathrm{Pkb}$ were investigated for density, hardness, and tensile properties. It was observed that addition of $\mathrm{Cb}$ and Ps in the cast $\mathrm{Pkb}$ gave a density of $2.68 \mathrm{~g} / \mathrm{cm}^{3}$ and $2.60 \mathrm{~g} / \mathrm{cm}^{3}$ respectively. The average values of hardness and tensile strength obtained were $41.18 \mathrm{BHN}$ and 135.88 MPa respectively when Ps was added to the cast aluminium Pkb, while addition of $\mathrm{Cb}$ gave harness values of $40.45 \mathrm{BHN}$ and tensile strength of $134.63 \mathrm{MPa}$.
\end{abstract}

Keywords: Turning, Coolant temperature, T16AL4V, Surface roughness, Machining Parameter

\section{INTRODUCTION}

The rate of wastes generation in modern day life has tremendously increased in which its composition and the magnitude generated have influence on the way the population lives [1]. Improper management of such wastes may have been accountable for degrading the environmental and the difficulty in its disposal [1,2]. This work focused on using aluminium alloy ( $\mathrm{Al}$ 6063) straps that is the off-cut generated from the production of aluminium doors and windows. The aluminium alloy off-cut was used as matrix while periwinkle shell (Ps) and cowbone (Cb) were used as reinforcements to form a composite for the production of prophylactic knee brace (Pkb) used in bone support. $\mathrm{Pkb}$ consists of the brace (metal), hinge (link point) and strap system. Pkb is usually used as components for knee injury management (preventive and healing mechanism) of knee injuries [3, 4].

Many works on reinforcement of aluminium have been carried out [5-12]. Among these, Umunakwe et al. [12] reported on mechanical properties and microstructures of Particulate Periwinkle Shell-aluminium 6063 Metal Matrix Composite (PPS-AIMMC) and comparing the properties of the composites with those of the aluminium 6063 (AA6063) alloy. Application of aluminium scrap for Pkb particularly with $\mathrm{Ps}$ and $\mathrm{Cb}$ as reinforcements is rarely available. The focus of this study is to investigate the hardness and tensile properties of Prophylactic Knee Brace Produced from Cow bone and Periwinkle Shell Composites

S. Abdulkareem¹, T. A. Adekaye1., A. T. Abdulrahim¹., Y. L. Shuaib-Babata²,, T. K. Ajiboye ${ }^{3}$., I. I. Ahmed²., H. K. Ibrahim $^{1}$ 局, J. A. Adebisi ${ }^{2}$ and T. Yahaya ${ }^{2}$

'Department of Mechanical Engineering

${ }^{2}$ Department of Materials \& Metallurgical Engineering

Faculty of Engineering \& Technology, University of Ilorin, P.M.B. 1515, Ilorin, Nigeria

${ }^{3}$ Department of Mechanical Engineering

Faculty of Engineering, University of Maiduguri, P.M.B. 1069, Maiduguri, Nigeria

E-mail: ibrahim.kh@unilorin.edu.ng

Reference: Abdulkareem S., Adekaye T. A., Abdulrahim A. T., Shuaib-Babata Y. L., Ajiboye T. K., Ahmed I. I., Ibrahim H. K., Adebisi J. A. and Yahaya T. (2019). Hardness and Tensile Properties of Prophylactic Knee Brace Produced from Cow Bone and Periwinkle Shell Composites. International Journal of Engineering Materials and Manufacture, 4(2), 41-47. 


\section{MATERIALS AND METHODS}

The materials used are: The off-cut (scraps) of Aluminium (Al 6063) (door and window frames) produced by Nigeria Aluminium Extrusions Limited, Lagos Nigeria. The Ps and Cb were sourced from river bank and abattoir respectively.

\subsection{PREPARATION OF SAMPLES}

\subsubsection{Preparation of Aluminium Scrap}

The aluminium scraps were cleaned and sun dried for 24 hours to remove dirt before charged into furnace (Model No. M254 and Serial No. AD3246P) for melting and de-slagging. The molten aluminium was stirred and cast into a rectangular bar. The solidified material was reduced to smaller sizes. The percentage composition of the aluminium alloy used is shown in (Table 1)

Table 1: Chemical composition of aluminium (Al 6063) off-cut [12]

\begin{tabular}{cccccccccccc}
\hline Element & $\mathrm{Al}$ & $\mathrm{Si}$ & $\mathrm{Fe}$ & $\mathrm{Cu}$ & $\mathrm{Mn}$ & $\mathrm{Mg}$ & $\mathrm{Zn}$ & $\mathrm{Cr}$ & $\mathrm{Ti}$ & $\mathrm{Ca}$ & Other \\
$\mathrm{Wt}_{\mathrm{t}} \%$ & 98.18 & 0.60 & 0.46 & 0.012 & 0.024 & 0.35 & $<0.002$ & 0.01 & 0.06 & 0.07 & 0.12 \\
\hline
\end{tabular}

\subsubsection{Preparation of Periwinkle Shell (Ps)}

The Ps (Figure 1) were cleansed by soaking for 24 hours, boiled in water and detergent at $100{ }^{\circ} \mathrm{C}$ for 50 minutes and cooled in air. The washing was carried out by wire brush to remove sand particles and dirt. It was later reduced into smaller sizes and sun dried for 7 days. The Ps was heated in an oven (Model SDO/225 Serial No. Y9C227) at $110{ }^{\circ} \mathrm{C}$ for 30 minutes to remove moisture as reported by Umunakwe et al., [12]. The chemical composition of Ps powder as used by Nwabufor [13] (Table 2). The Ps was crushed with Denver laboratory ball mill (Model 48-D0500/0 with Serial No. 14002201). Pulverized and sieved to $75 \mu \mathrm{m}$ particle size using BS standard sieves (Figure 2).

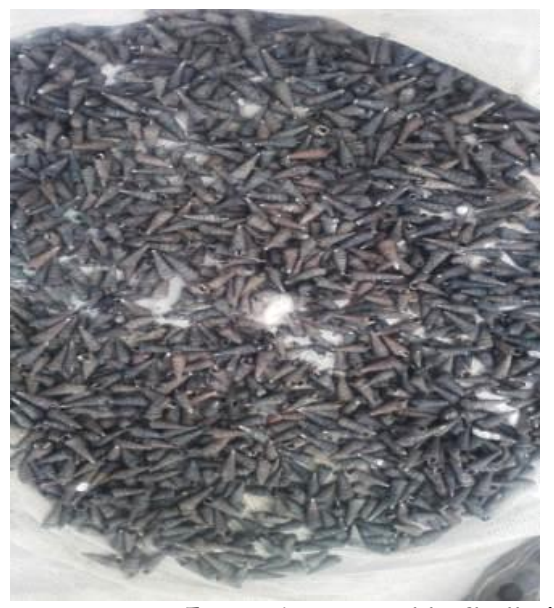

Figure 1: Periwinkle Shells (Ps)

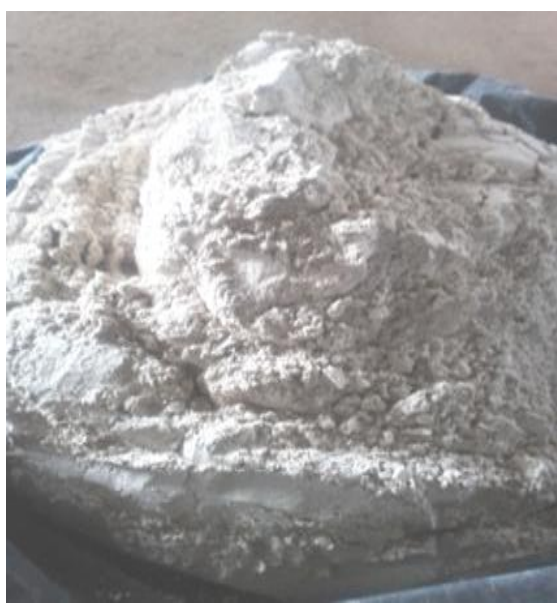

Figure 2: Pulverized Periwinkle Shell

Table 2: Chemical composition of periwinkle shell powder [13].

\begin{tabular}{cccccccccccc}
\hline Constitute & $\mathrm{SiO}_{2}$ & $\mathrm{Al}_{2} \mathrm{O}_{3}$ & $\mathrm{Fe}_{2} \mathrm{O}_{3}$ & $\mathrm{CaO}$ & $\mathrm{MgO}$ & $\mathrm{SO}_{3}$ & $\mathrm{~K}_{2} \mathrm{O}$ & $\mathrm{Na}_{2} \mathrm{O}$ & $\mathrm{Mn}_{2} \mathrm{O}_{3}$ & $\mathrm{P}_{2} \mathrm{O}$ & $\mathrm{TiO}_{2}$ \\
Composition (\%) & 32.84 & 10.20 & 7.02 & 40.84 & 1.47 & 0.26 & 0.14 & 0.24 & 0.78 & 0.01 & 1.07 \\
\hline
\end{tabular}

\subsubsection{Preparation of Cow Bone (Cb)}

The $\mathrm{Cb}$ bones were soaked for 24 hours, scraped to remove meat remnants. The bones were boiled in waterdetergent at $100{ }^{\circ} \mathrm{C}$ for 90 minutes in other to remove fat and oil and thereafter cooled in air as equally reported by Zainal and Hamdzun [14]; Sangeeta et al., [15]; Abdulrahman et al., [16]. The bones were further scrubbed with wire brush in warm water before size reduction by the use of sledge hammer and sun dried for 4 weeks to reduce the moisture $[9,17]$. Calcination of the bones were effected in oven (Model SDO/225 with Serial No. Y9C227) at 300 ${ }^{\circ} \mathrm{C}$ for 2 hours to ensure elimination of protein $[14,18]$. Denver laboratory ball mill (Model 48-D0500/0 with Serial No. 14002201) was used to crush the bones and pulverized to $75 \mu \mathrm{m}$ particle size according to BS1377:2014. The chemical composition of cow bone (Table 3) was adopted from Sergius and Janecek [19]. 
Table 3: Chemical composition of cow bone powder (wt\%) [19]

\begin{tabular}{cccccc}
\hline Metal & $\mathrm{Ca}$ & $\mathrm{Mg}$ & $\mathrm{K}$ & $\mathrm{P}$ & $\mathrm{CO}$ \\
\% Composition & 36.05 & 0.74 & 0.85 & 16.43 & 4.58 \\
\hline
\end{tabular}

\subsection{CASTING OF PROPHYLACTIC KNEE BRACE (Pkb) COMPOSITES}

\subsubsection{Melting and Casting of the Brace}

The production of the $\mathrm{Pkb}$ aluminium composite was achieved using the stir casting method

$[12,20]$. The samples were produced by varying the percentage of reinforcing $C b$ and Ps particles at $(1,2,4,6,8$ and 10) wt \% of the same $75 \mu \mathrm{m}$ particle size. The aluminium alloy of mass $292 \mathrm{~g}$ was charged into the furnace, which was heated to $850{ }^{\circ} \mathrm{C}$ to ensure complete melting of the alloy.

\subsubsection{Production of Pkb Composite}

In the production of Pkb composite, the furnace temperature was raised to $850{ }^{\circ} \mathrm{C}$ and the molten aluminium alloy was allowed to cool in the furnace to a temperature of $700{ }^{\circ} \mathrm{C}$ [12]. The Ps was preheated to $200{ }^{\circ} \mathrm{C}$ for 1 hour to improve the materials wettability [21]. The preheated Ps was added and stirred for 5 minutes. The composite slurry was re-heated to a temperature of $850{ }^{\circ} \mathrm{C}$ and thoroughly stirred for 5 minutes before the melt was poured into a preheated mould with diameter $250 \mathrm{~mm}$ and $300 \mathrm{~mm}$ length used to prepare cast braces (Figure 3 and 4). The pouring of the melt was maintained at laminar flow to avoid entrapped air. The same procedure was adopted for the casting of $\mathrm{Cb}$ aluminium composite with addition of $0.5 \mathrm{wt} \% \mathrm{Mg}$ for good wettability of particles with molten metal [21].

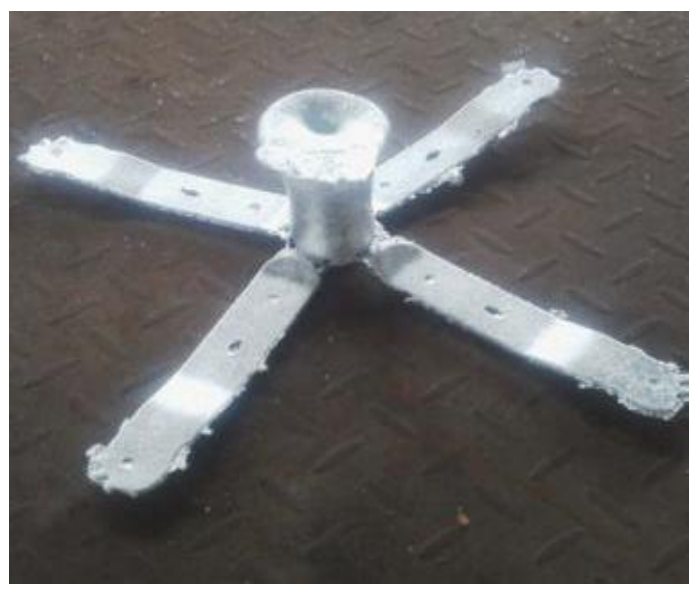

Figure 3: Cast Brace Composite

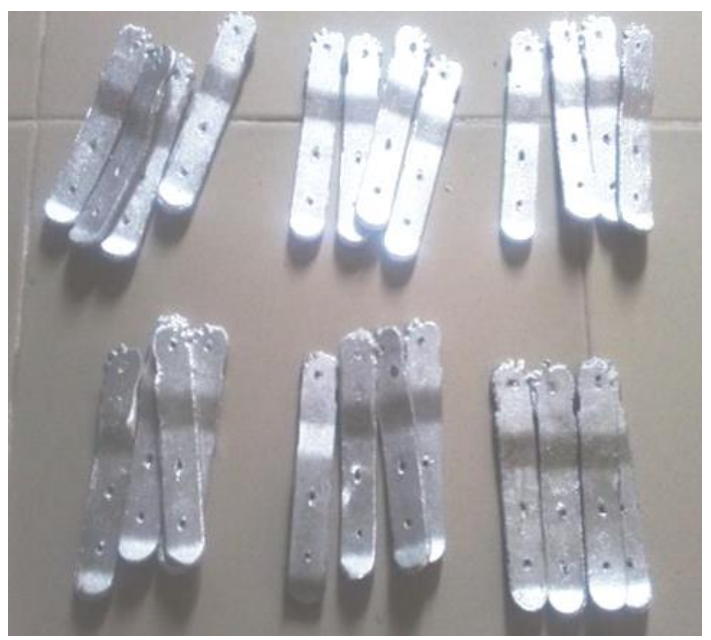

Figure 4: Finished Cast Brace Composite 


\section{RESULTS AND DISCUSSSIONS}

3.1 Determination of the Density

The density measurements of the samples were carried out using the Archimedes's principle, which states that a body immersed in a fluid is buoyed up by a force equal to the weight of the displaced fluid. The relative density $R_{D}$ is obtained using equation 1 [20].

$$
R_{D}=\frac{W_{a}}{W_{a}-W_{w}}
$$

Where, $R_{D}=$ Relative density of the composite sample, $W_{a}=$ weight of the composite in air, $W_{w}=$ weight of the composite in water.

The density (Figure 5) of the reinforced Ps composites reduced from $2.72 \mathrm{~g} / \mathrm{cm}^{3}$ at 1 wt $\%$ of Ps addition to 2.60 $\mathrm{g} / \mathrm{cm}^{3}$ at $10 \mathrm{wt} \%$ of Ps addition. The density of the reinforced $\mathrm{Cb}$ composites also reduced from $2.72 \mathrm{~g} / \mathrm{cm} 3 \mathrm{at} 1 \mathrm{wt}$ $\%$ of $\mathrm{Cb}$ addition to $2.68 \mathrm{~g} / \mathrm{cm} 3$ at 10 wt \% of $\mathrm{Cb}$ addition.

The reduction in density of the cast $\mathrm{Pkb}$ was more significant in $\mathrm{Ps}$ composites compared to that of $\mathrm{Cb}$ composites. The reduction could be because of less dense property of Ps particles as against the $\mathrm{Cb}$ particles. The decrease in density with addition of the particulates could be because of the lower density of the fillers compared to that of aluminium metal matrix. This is good because it will enhance the utilization of $\mathrm{Al} / \mathrm{Ps}$ and $\mathrm{Al} / \mathrm{Cb}$ metal composites where lighter weight is desired properties. This is in agreement with the work of [12] and [21].

Fig 5 shows the densities of the $\mathrm{Al} / \mathrm{Ps}$ and $\mathrm{Al} / \mathrm{Cb}$ composites produced with that of control and original material $(O M)$ used for $\mathrm{Pkb}$. It can be observed that the density of the control and $\mathrm{OM}$ is $2.73 \mathrm{~g} / \mathrm{cm}^{3}$ and is higher than that of $\mathrm{Al} / \mathrm{Ps}$ and $\mathrm{Al} / \mathrm{Cb}$. The density of Ps reinforced composite is lower compared to the density of $\mathrm{Al} / \mathrm{Cb}$, control and $\mathrm{OM}$. The density of $\mathrm{Al} / \mathrm{Ps}$ composite falls within the range of density of aluminium material used for Pkb.

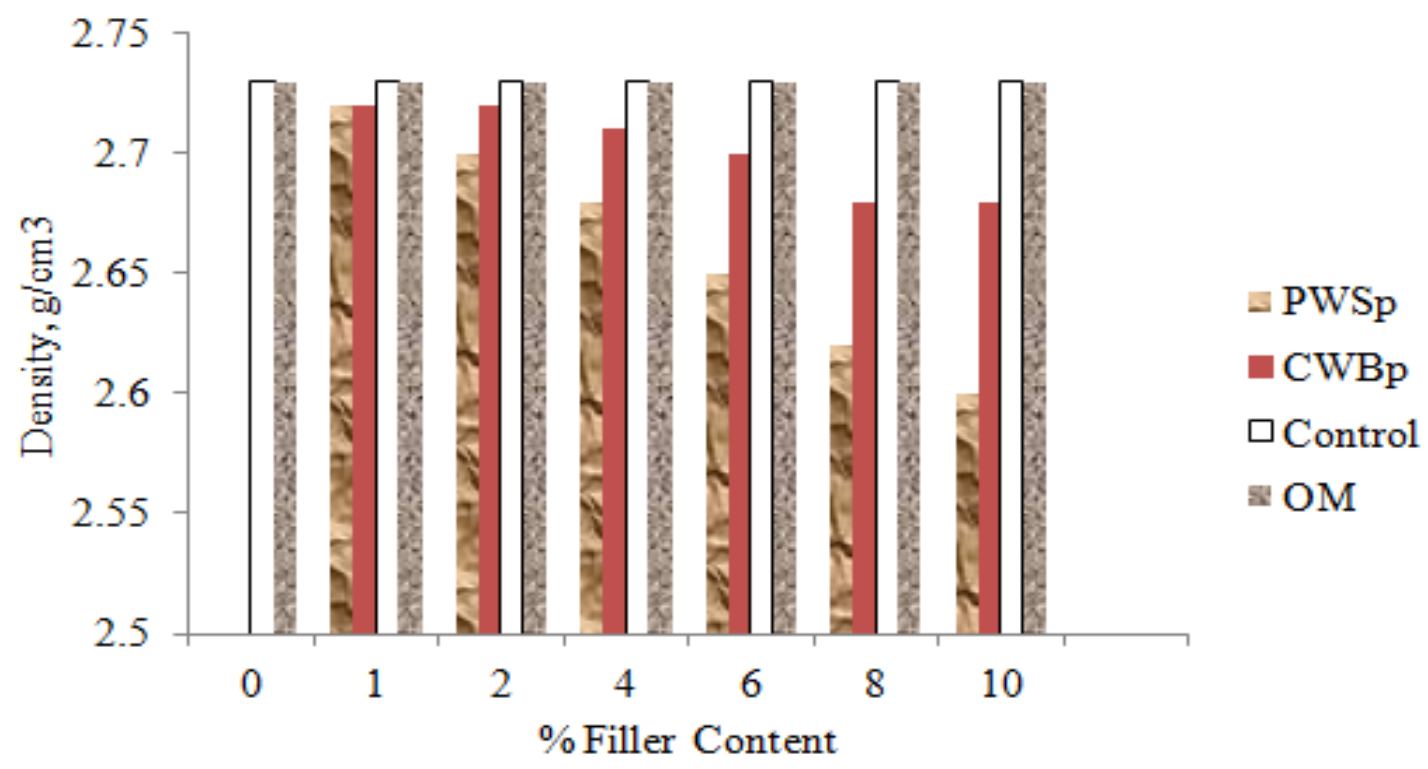

Figure 5: Density of the $\mathrm{Al} / \mathrm{Ps}$ and $\mathrm{Al} / \mathrm{Cb}$ composites $\mathrm{Vs}$ control sample and $\mathrm{OM}$

\subsection{Hardness Property}

The hardness properties of the samples (Figure 6) were determined according to ASTM E10 standard procedure using Brinell Hardness Tester (Edibon Brinell Tester, Model EEDB, and Serial No. EEDB0006/13). The machine indenter of diameter $5 \mathrm{~mm}$ and load $2500 \mathrm{~N}$ with dwelling time of $15 \mathrm{sec}$ was used. According to [22], the average diameter of indentation was used to determine the hardness number of the composites using Equation 2.

$$
H B=0.102 \times \frac{2 F}{\pi D\left(D-\sqrt{D^{2}-d^{2}}\right)}
$$

Where, $F=$ Test Force $(N), D=$ Diameter of steel ball $(\mathrm{mm}), d=$ Diameter of indentation $(\mathrm{mm})$

Table 4 shows the hardness values of the produced composites with \% wt PwS and \% wt $\mathrm{Cb}$, the hardness values of the cast $\mathrm{Al} / \mathrm{Ps}$ composites increased as the \% wt Ps addition increases in the aluminium alloy while that of $\mathrm{Al} / \mathrm{Cb}$ 
initially decreased sharply before steady increases before decreasing. The hardness value of composites increased from 40.30 HBN to $41.80 \mathrm{HBN}$ at $10 \mathrm{wt} \%$ addition of Ps. The presence of the hard ceramic phase in the ductile matrix resulted into the increase in the hardness of the $\mathrm{Al} / \mathrm{Ps}$ composite from $40.50 \mathrm{HBN}$ to $41.80 \mathrm{HBN}$ for 1 wt $\%$ and 10 wt \% Ps respectively. The $\mathrm{Al} / \mathrm{Cb}$ composites increased in hardness from $40.10 \mathrm{HBN}$ for $1 \mathrm{wt} \%$ up until $40.80 \mathrm{HBN}$ for $6 \%$ wt cow bone particles where it gradually decreased to $40.40 \mathrm{HBN}$ at $10 \mathrm{wt} \%$ of cow bone particles.

The decrease in hardness of the $\mathrm{Cb}$ composite might be due to poor wettability and poor filler dispersion at higher weight fraction and the increments of hardness of Al/Ps was attributed to increase in weight percentage of hard and brittle phase of the Ps particles in the aluminium alloy. The increase in hardness could be due to the effect of the increase in the interfacial contact area between the matrix and the reinforcement.

This hardness experience in the $\mathrm{Ps}$ composites is likely to be from $\mathrm{SiO}_{2}, \mathrm{Al}_{2} \mathrm{O}_{3}, \mathrm{CaO}$ and $\mathrm{Fe}_{2} \mathrm{O}_{3}$ present. Figure 6 shows the hardness value recorded for the produced aluminium particulates composites and control as well the OM It was observed that $\mathrm{Al} / \mathrm{Ps}$ composites possess the average highest hardness values of $41.18 \mathrm{BHN}$ followed by the $\mathrm{Al} / \mathrm{Cb}$ composites with $40.45 \mathrm{BHN}$ as compared to control with $40.30 \mathrm{BHN}$ used for Pkb.

Table 4: Hardness values of Al-wt \% Ps and Cb knee brace produced

\begin{tabular}{cccc}
\hline Percentage composition of $\mathrm{Al} / \mathrm{Ps}$ and & \multicolumn{2}{c}{ Hardness (BHN) } \\
\cline { 2 - 4 } $\mathrm{Al} / \mathrm{Cb}$ & Periwinkle shell & Cowbone \\
\hline $99 \%$ & $1 \%$ & 40.50 & 40.10 \\
$98 \%$ & $2 \%$ & 40.80 & 40.30 \\
$96 \%$ & $4 \%$ & 41.20 & 40.60 \\
$94 \%$ & $6 \%$ & 41.30 & 40.80 \\
$92 \%$ & $8 \%$ & 41.50 & 40.50 \\
$90 \%$ & $10 \%$ & 41.80 & 40.40 \\
\hline
\end{tabular}

Hardness value of control sample $=40.30$

Hardness value of original material $=40.50$

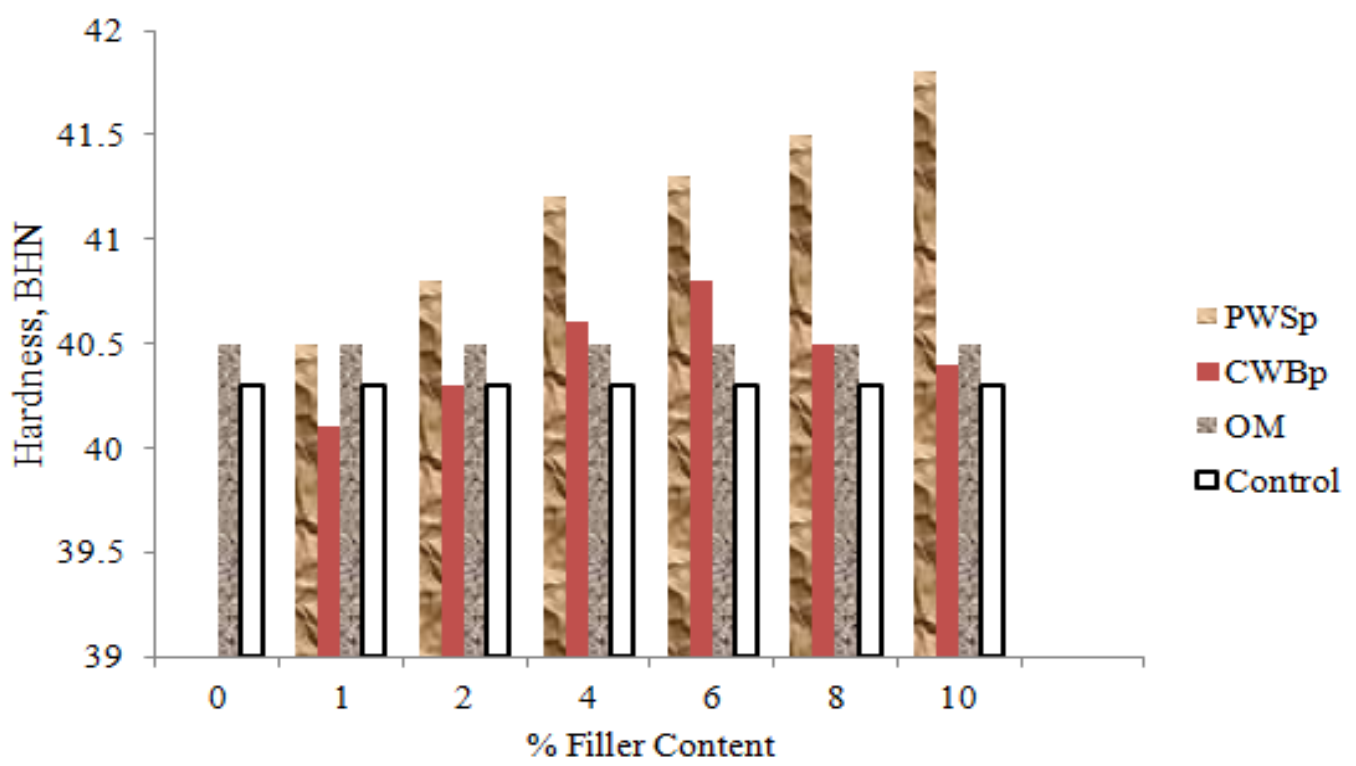

Figure 6: Hardness values for $\mathrm{Al} / \mathrm{Ps}$ and $\mathrm{Al} / \mathrm{Cb}$ with Control and $\mathrm{OM}$

\subsection{Tensile Strength}

The results of the tensile strength (Table 5) revealed that the tensile strength of the aluminium alloy was improved with increasing weight fraction of the reinforcements (Ps and $\mathrm{Cb}$ ). This was due to the increase in the percentage of $\mathrm{Ps}$ and $\mathrm{Cb}$ particulates, which is likely to result in production of more calcium silicate giving higher strength in the composite produced. $\mathrm{Al} / 10 \mathrm{wt} \% \mathrm{Ps}$ samples give more strength ( $140.30 \mathrm{MPa}$ ) while the $\mathrm{Al} / 10 \mathrm{wt} \% \mathrm{Cb}$ gives strength value of $138.20 \mathrm{MPa}$ which is lower than that obtained from PwS sample, hence Ps impacts more strength in aluminium than the $\mathrm{Cb}$. This result may be attributed to the strengthening effect of the particulates on the aluminium alloy matrix. This behaviour is in agreement with the work of Nwabufor [13], Agunsoye et al, [18] and Aigbodion, 
[21]. Figure 7 shows the tensile strength of $\mathrm{Al} / \mathrm{Ps}$ and $\mathrm{Al} / \mathrm{Cb}$ composites produced with control and $\mathrm{OM}$. The tensile strength of the control sample is lower compared to that of OM. When the addition of $\mathrm{Ps}$ and $\mathrm{Cb}$ from 1-10 wt \% was made, it was observed that the tensile strength of the aluminium composites increased significantly and had higher values compared to the control and OM.

Table 5: Tensile strength of Al-wt \% Ps and Cb knee brace produced

\begin{tabular}{cccc}
\hline Percentage composition of $\mathrm{Al} / \mathrm{Ps}$ and $\mathrm{Al} / \mathrm{Cb}$ & \multicolumn{2}{c}{ Tensile strength (MPa) } \\
\cline { 3 - 4 } 9 & $1 \%$ & 131.50 & Cow bone \\
\hline $98 \%$ & $2 \%$ & 132.80 & 130.90 \\
$96 \%$ & $4 \%$ & 135.70 & 131.50 \\
$94 \%$ & $6 \%$ & 136.90 & 133.70 \\
$92 \%$ & $8 \%$ & 138.10 & 137.90 \\
$90 \%$ & $10 \%$ & 140.30 & 138.20 \\
\hline
\end{tabular}

Tensile strength of control sample $=130.10 \mathrm{MPa}$

Tensile strength of $\mathrm{OM}=135.17 \mathrm{MPa}$

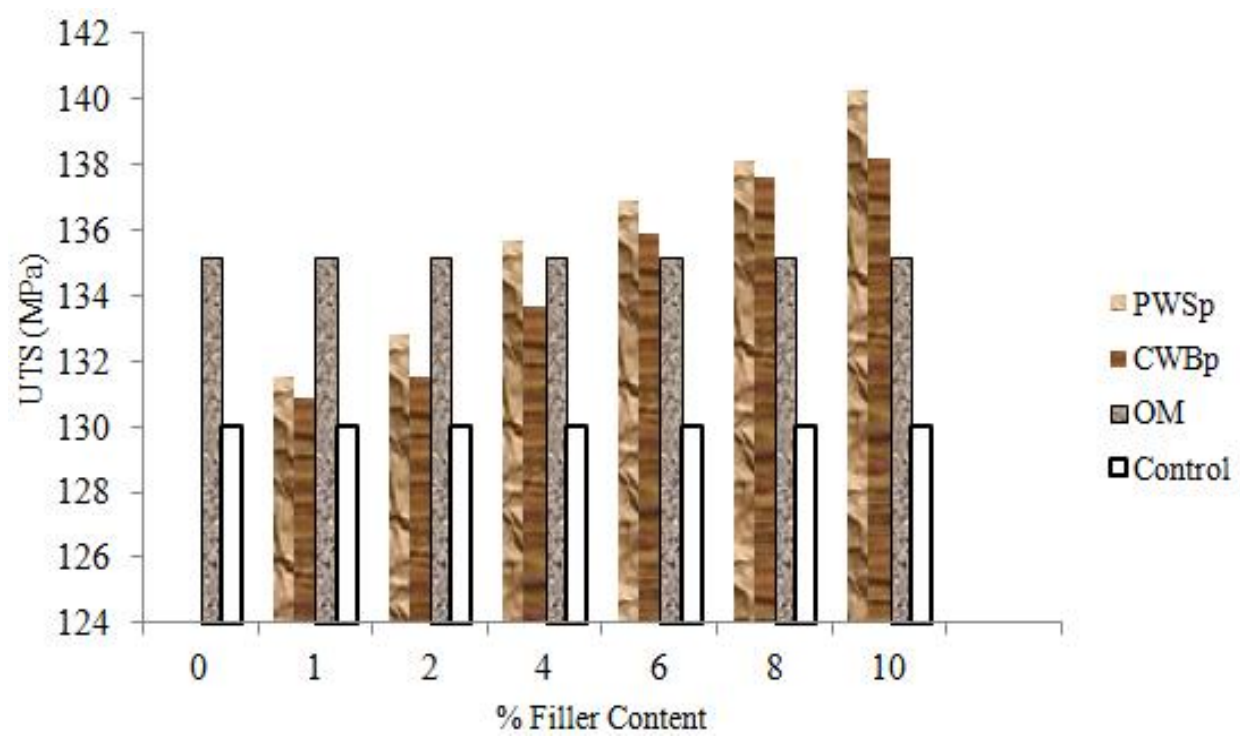

Figure 7: Tensile strength of $\mathrm{Al} / \mathrm{Ps}$ and $\mathrm{Al} / \mathrm{Cb}$ with control and $\mathrm{OM}$

\section{CONCLUSIONS}

Investigation on hardness and tensile properties of prophylactic knee brace produced from cow bone and periwinkle shell composites, using Ps and $\mathrm{Cb}$ as reinforcements has been reported. The evaluations of the hardness and tensile properties of the cast aluminium brace, has necessitated the following conclusions:

1. Aluminium composite of lightweight can be produced using $\mathrm{Ps}$ and $\mathrm{Cb}$ because the density of the produced $\mathrm{Al} / \mathrm{Ps}$ and $\mathrm{Al} / \mathrm{Cb}$ composites reduced with increase in the addition of $\mathrm{Ps}$ and $\mathrm{Cb}$.

2. The tensile strength of 140.30 and $138.20 \mathrm{MPa}$ were obtained for $90 \%$ cast aluminium base metal matrix composite with $10 \%$ weight percent addition of $\mathrm{Ps}$ and $\mathrm{Cb}$ particles respectively. The tensile strength of cast aluminium base metal matrix composite increases as weight percent addition of Ps and Cb particles increases.

3. The hardness of the Al/Ps composites increased as the \% wt Ps addition increases in the cast aluminium alloy.

\section{FURTHER WORK}

Investigation on the impact and buckling properties on the cast Pkb with Ps and $\mathrm{Cb}$ particulates as reinforcements is to be carried out.

\section{ACKNOWLEDGEMENT}

The authors wish to acknowledge the assistance of Mr. Mustapha Ndagi of the Department of Mechanical Engineering, University of Ilorin, Nigeria for his guidance. 


\section{REFERENCES}

1. De Sousa F. D. B and Zanchet A. (2018). In the Search for Sustainable Processing in Compounds Containing Recycled Natural Rubber: The Role of the Reversion Process. Recycling 2018, 3, 47; doi:10.3390/recycling3040047. Multidiciplinary Digital Publishing Institute, Switzerland

2. De Sousa, F. D. B. (2017). Devulcanization of elastomers and applications. In Elastomers; Çankaya, N., Ed.; Intech: Rijeka, Croatia, Chapter 10, pp. 209-230.

3. Mortaza, N., Abu, O., Jamshidi, A., \& Razjoyah, J. (2013). "Influence of Functional Knee Bracing on the Isokinetic and Functional Tests of Anterior Cruciate Ligament Deficient Patents". PLOS ONE, 8 (5).

4. Yusran, P., \& Natinee, L. (2009). "Adhesion of Pineapple - Leaf Fiber to Epoxy Matrix: The Role of Structure Treatments". Journal of Science and Technology, 31 (2), 189-194.

5. Ankesh, K., Kanhaiya, K., \& Suman, S. a. (2016). "Study of physica, Mechanical and Machinability Properties of Aluminium Metal Matrix Composite Reinforced with Coconut Shell Ash Particulates". Imperial Journal of Interdisciplinary Research (IJIR), 2, 151-157.

6. Arun, P., Shanmughasundaram, P., Suganthi, S., Kumar, R., \& Vijay, a. (2016). "Wear Behaviour of Al-Chicken Bone Ash Metal Matrix Composites". Journal of Advances in Natural and Applied Sciences, 10 (6), 11-15.

7. Oladele, I. O., \& Isola, B. A. (2016). "Development of Bone Particulate Reinforced Epoxy Composite for Biomedical Application". Journal of Biotechnology \& Bioengineering, 1 (1).

8. Das, D., Mishra, P. C., \& Singh, S. a. (2014). Properties of Ceramic- Reinforced Aluminium Matrix Composites A Review". International Journal of Mechanical and Materials Engineering, 1 (12), 1-16.

9. Oladele, O. I., Daramola, O. O., \& Adewole, A. T. (2014). "Comparative Study of the Reinforcement Efficiency of Cow Bone and Cow Bone Ash in Polyester Matrix Composites for Biomedical Applications". Bulletin of Engineering, Tome VII, 27-34.

10. Michael, I. O., Fidelis, I. A., \& Ikpi, U. U. (2012). "Mechanical Properties of Hybrid Periwinkle and Rice Husk Filled CNSL Composite". International Journal of Nano and Material Sciences, 1 (2), 74-80.

11. Purohit, R., Rana, R. S., \& Verma, C. S. (2012). "Fabrication of Al - SiCp Composites through Powder Metallurgy Process and Testing of Properties". International Journal of Engineering Research and Applications, 2 (3), 420437.

12. Umunakwe, R., Olaleye, D. J., Oyetunji, A., Okoye, O. C., \& Umunakwe, I. J. (2017). "Assessment of Some Mechanical Properties and Microstructure of Particulate Periwinkle Shell - Aluminium 6063 Metal Matrix Composite (PPS-AIMMC) produced by Two-Step Casting". Nigerian Journal of Technology (NIJOTECH), 36 (2), 421-427.

13. Nwabufor, M. N. (2015). "Development and Characterization of AL - 3.7\% Cu - 1.4\% Mg Alloy / Periwinkle Ash (Turritella Communis) Particle Composites". Ahmadu Bello University, the Department of Metallurgical and Materials Engineering, Zaria.

14. Zainal, Z., \& Hamdzun, H. (2014). "Characterization of Local Bone Ash for Bone China Production". Journal of Technology (Sciences and Engineering), 66 (1), 25-34.

15. Sangeeta, P., Jie, H., Wei, Q., \& Wei, G. (2015). "Synthesis and Characterization of Mesoporous Bone Char Obtained by Pyrolysis of Animal Bones, for Environmental Application". Journal of Environmental Chemical Engineering, 2368-2377.

16. Abdulrahman, A., A., L., Daud, Z., \& Ridzuan, M. B. (2016). "Preparation and Characterization of Activated Cow Bone Powder for the Adsorption of Cadmium from Palm Oil Mill Effluent". Materials Science and Engineering, 136, 1-6.

17. Oladele, I. O., \& Adewole, T. A. (2013). "Influence of Cow Bone Particle Size Distribution on the Mechanical Properties of Cow Bone - Reinforced Polyester Composites". Biotechnological Research International, 2013, 1-5.

18. Agunsoye, J., Talabi, S., \& Awe, O. A. (2013). "Mechanical Properties and Tribological Behaviour of Recycled Polyethylene/Cow Bone Composite". Journal of Materials Science Research, 2 (2), 41-50.

19. Sergius M. \& Janecek, E. (1931). Studies on the Chemical Composition of Bone Ash, J. Biol. Chem., 93:455-466, http://www.jbc.org/content/93/2/455.

20. Alaneme K. and Bodunrin, M. (2013). "Mechanical Behaviour of Alumina Reinforced AA6063 Metal Matrix Composites Developed by Two-step Casting Process". ACTA Technical Corviniensis-Bulletin of Engineering, 6 (3), 105-110.

21. Aigbodion, V. S. (2010). In A. V. S., "The Development and Characterization of Al-Cu-Mg/Bagasse Ash Particulate Composites" (pp. 17-70). Department of Metallugical Engineering, Zaria.

22. Asuke, F., Aigbodion, V., Abdulwahab, M., Fayemi, O., Popoola, A. P., \& Nwoyi, C. I. (2012). "Effect of Bone Particle on the Properties and Microstructure of Polypropylene/bone Ash Particulate Composites". Journals of Elsevier, 135-141. 